\title{
Irrigation and water security: the role of economic instruments and governance
}

\author{
R. C. de Loë ${ }^{1} \&$ H. Bjornlund ${ }^{2,3}$ \\ ${ }^{1}$ Guelph Water Management Group, Department of Geography, \\ University of Guelph, Canada \\ ${ }^{2}$ Department of Economics, University of Lethbridge, Canada \\ ${ }^{3}$ University of South Australia, Adelaide, Australia
}

\begin{abstract}
Irrigation is an important contributor to global food security. However, it also contributes to a number of serious water management problems in countries around the world, including groundwater subsidence, reduced water quality, salinization and degraded ecosystems. Steps are being taken to modernize irrigation, both in terms of technologies and institutions. Importantly, while improvements within the irrigation sector are critical, they alone will not ensure the continued sustainability of the sector because irrigation contributes to, and is affected by, the larger challenge of ensuring water security. In this paper, we explore the concept of water security and link it to irrigation through examining the link between water allocation and water security. Economic instruments, we argue, are an important part of strategies to improve allocative efficiency and thus they promote water security - but on their own they are not sufficient. Rather, we suggest that water security as a multi-dimensional challenge must be approached from the broader perspective of improved governance. In this context, attention is needed to considerations such as transparency in decision making; equity in stakeholder involvement; integration among related systems (e.g., land and water, water and economy); the scale of decision making; and the balance between state and non-state actors.
\end{abstract}

Keywords: water governance, irrigation, economic instruments, water security.

\section{Introduction}

Irrigation increases agricultural yields and outputs and helps to stabilize global food production. The roughly $17 \%$ of the world's cropland that is irrigated 
produces over one-third of the food and fibre grown globally (Oster and Wichelns [15]). Irrigation's importance in the global food system is expected to increase. Approximately 250 million hectares of land are irrigated worldwide, a five-fold increase relative to the beginning of the 20th century (Rosegrant et al. [16]). Expansion in the amount of land irrigated is likely in future, with the bulk occurring in developing countries where population growth and demand for increased food production are strongest (WWAP [18]).

Balanced against the benefits of irrigation for food security are its environmental costs. Agricultural production is by far the largest consumer of water, with up to $70 \%$ of water withdrawals being used in irrigation [18]. Globally, water withdrawals for irrigation are estimated at about 2,000 to 2,500 $\mathrm{km}^{3}$ per year. However, on average only $40 \%$ of this water contributes directly to crop production, with the remainder lost to evaporation, infiltration or weed growth [18]. In many parts of the world irrigation practices have resulted in lowered groundwater levels, salinization of soils, reduced water quality, alteration and regulation of natural watercourses, and reduced surface water availability (Dougherty and Hall [7], Rosegrant et al. [16], WWAP [18]). Poor drainage and irrigation practices are estimated to have caused waterlogging and salinization in $10 \%$ of the world's irrigated land [18].

In lights of its importance for global food production and food security [16], and considering its implications for the quality and quantity of water resources, effective irrigation water management is a global priority. Whether or not current levels of irrigation are sustainable, and whether or not additional irrigation is possible, clearly depends strongly on the availability of water supplies. These supplies are not assured because demand for increasingly scarce fresh water supplies is growing rapidly around the world from a variety of human uses. Simultaneously, expectations regarding environmental quality are growing. Maintenance and enhancement of aquatic ecosystems has emerged as a priority in many parts of the world. As a result, demands for water resources in many regions where pressure already exists are increasing as environmental needs are addressed.

In this chapter, we explore links between irrigation and the concept of "water security". We argue that irrigation is an important determinant of water security and, at the same time, we suggest that broader water security concerns influence the long-term viability of the irrigation sector. Water allocation systems can be an important vehicle for enhancing water security. Economic instruments are a key part of any strategy to reform water allocation systems in ways that promote water security, but numerous other concerns relating to governance also must be addressed.

\section{Water security as a governance challenge}

"Water security" is a multi-dimensional concept that has widely differing interpretations. For example, in the United States, fears about terrorist attacks have spawned an industry focused on identifying vulnerabilities in drinking water systems (e.g., Haestad Methods [12]). A much broader perspective on 
water security is offered by the Global Water Partnership (GWP), which defines it as "access to adequate quantities of water, of acceptable quality, for human and environmental uses" (GWP [10]). It is the broader perspective of the GWP that informs this paper. Water security exists when sufficient water of good quality is available for social, economic and cultural uses while, at the same time, adequate water is available to sustain and enhance important ecosystem functions (de Loë et al. [5]). Achieving water security is challenging because it requires good governance.

Governance refers to the processes through which societies make decisions that affect water. Good water governance depends on broad participation by affected stakeholders, and is characterized by transparency, equity, accountability, coherence, responsiveness, ethical choices, and integration of water decision making with other pertinent concerns [18]. Increasingly, people concerned about governance explicitly recognize that decision making regarding water should involve not only governments, but also citizens, non-governmental organizations and businesses.

One specific area in which links between water security and good governance are strong is water allocation. Water allocation systems are the rules and procedures through which access to water for both consumptive and nonconsumptive uses is determined. By establishing the availability and priority of access to water resources for consumptive uses such as irrigation, cities, and manufacturing, and for non-consumptive uses such as hydropower, recreation and environmental protection, water allocation systems influence economic productivity, social and cultural wellbeing and ecosystem quality (Gleick [9]; Ferreyra and Van Beek [8]; Warner et al. [17]).

The socioeconomic, cultural and ecological implications of water allocation are amplified when water resources become scarce due to population growth, climate change, and changes in societal preferences. In the context of scarcity whether created by societal or natural processes - water allocation systems can increase or decrease water security. Thus, effective, efficient, and equitable water allocation systems are critical to maintaining and enhancing environmental quality, economic productivity, and social wellbeing. This is especially true in regions where local economies are strongly dependent on irrigated agriculture (Bjornlund [3]).

\section{Irrigation, water security and governance}

Modernization of irrigation systems is occurring throughout the world through upgrading of infrastructure and through improving water use efficiency and productivity in agriculture. This is being accomplished with technologies such as drip irrigation and laser-leveling, and through procedures such as improved irrigation scheduling; measures such as these permit water application in the optimum quantity and timing for crop development [15], [18].

Improvements in irrigation technologies and practices are not the sole focus of attempts to modernize the industry. Considerable attention also is being paid to adapting institutional arrangements and irrigation policies in order to change 
the focus from developing new water supplies to a more holistic approach which considers agricultural productivity and market conditions. Reform of water allocation systems and increased use of economic instruments is seen as a priority (Bjornlund [2], Dinar and Mody [6], WWAP [18], Young and McColl [19]).

Technological and institutional improvements within the irrigation sector are important contributors to its long-term viability. To the extent that they lead to more efficient water use and reduced impacts on land and water resources, they also may contribute to water security. However, improved practices and institutions within the sector will not be sufficient on their own to ensure water security, and thus the continued viability of the irrigation sector. As Bazzani et al. [1] have noted, "Irrigated agriculture is currently confronted with many issues relating to its role within the overall management of water at basin level." This suggests that what is also required is attention to the broader factors that shape water security in any particular place. These factors can be revealed through consideration of the links between water allocation systems and water security.

Considerations such as the ones outlined in Table 1 determine the extent to which sufficient water of good quality is available for social, economic and cultural uses while, at the same time, adequate water is available to sustain and enhance important ecosystem functions. For example, the need to find a balance between environmental and socio-economic concerns is strongly evident in concern for ecosystem protection, on the one hand, and economic production, on the other (Table 1).

- Water security is enhanced when water allocation systems recognize the need to provide water in appropriate amounts, and at appropriate times, to support environmental needs, and when they incorporate mechanisms for monitoring and enforcing environmental water allocations, and are sufficiently flexible to permit the use of new ecological knowledge.

- Equally, water security is promoted by allocation rules that are clear and stable, by systems that provide information needed to make economically sound decisions, and by mechanisms that promote allocative efficiency.

As is illustrated by Table 1, economic instruments should be part of any strategy to enhance water security. A well developed literature exists that explores approaches to improving efficiency in water allocation generally, and in the specific context of irrigation (e.g., Grimble [11], Kemper [13], Bjornlund [2], Dinar and Mody [6], Cantin et al. [4]). However, increase allocative efficiency in irrigation by itself is unlikely to ensure the sustainability of irrigation (Massarutto [14]), let alone water security. In light of the numerous ways in which agricultural water use affects communities and the natural environment [1], additional concerns are critical. These include the development of scientifically-sound bases for environmental water allocation; collection and dissemination of information needed to make economically sound decisions; creation of mechanisms to address conflicts at different scales, and to permit sustained in meaningful stakeholder and public participation; development and implementation of technologies and practices that promote water conservation; 
consideration of the impacts of climate very ability to change on water resources and water allocation systems; incorporation of adaptation strategies in water allocation decision making; attention to state sovereignty; and, in areas where indigenous people exist, respect for indigenous customary water allocation systems.

Table 1: $\quad$ Linking water allocation and water security.

\begin{tabular}{|c|c|}
\hline $\begin{array}{l}\text { Broad Water Security } \\
\text { Consideration }\end{array}$ & Specific Concerns Pertinent to Water Allocation \\
\hline Ecosystem Protection & $\begin{array}{l}\text { - Environmental water allocation } \\
\text { - Monitoring and enforcement for ecosystem } \\
\text { protection } \\
\text { - Creation and incorporation of ecological } \\
\text { knowledge }\end{array}$ \\
\hline Economic Production & $\begin{array}{l}\text { - Clear and stable allocation rules } \\
\text { - Water allocation and related information to } \\
\text { make economically sound decisions } \\
\text { - Ability to re-allocate water between users, } \\
\text { sectors and/or regions }\end{array}$ \\
\hline Equity and Participation & $\begin{array}{l}\text { - Equity } \\
\text { - Sustained and meaningful stakeholder and } \\
\text { public participation } \\
\text { - Mechanisms to address potential conflicts at } \\
\text { different scales }\end{array}$ \\
\hline Integration & $\begin{array}{l}\text { - Integration between groundwater and surface } \\
\text { water resources occurs } \\
\text { - Integration between water quality and water } \\
\text { quantity } \\
\text { - Integration between land use planning and water } \\
\text { allocation }\end{array}$ \\
\hline Water Conservation & $\begin{array}{l}\text { - Conservation-related charges } \\
\text { - Re-allocation of water to more efficient and less } \\
\text { consumptive uses } \\
\text { - Incorporation of water conservation practices }\end{array}$ \\
\hline $\begin{array}{l}\text { Climate Variability and } \\
\text { Change }\end{array}$ & $\begin{array}{l}\text { - Investments to understand impacts of climate } \\
\text { variability and change } \\
\text { - Development and application of adaptation } \\
\text { strategies }\end{array}$ \\
\hline $\begin{array}{l}\text { Transboundary } \\
\text { Sensitivity }\end{array}$ & $\begin{array}{l}\text { - Coordination of water allocation systems across } \\
\text { political boundaries } \\
\text { - Respect for state sovereignty } \\
\text { - Respect for indigenous customary allocation }\end{array}$ \\
\hline
\end{tabular}

Source: Adapted from de Loë et al. [5].

The extent to which many of these concerns can be addressed successfully depends strongly on the effectiveness of governance. Dinar and Mody [6] 
emphasize the importance of creating appropriate institutional frameworks within which policies relating to water pricing and cost recovery should be developed and implemented. This is an important consideration. However, from the broad perspective of water security, effective governance depends on much more than the institutional frameworks within which economic instruments are established and used. This was illustrated in a recent study of the links between water allocation and water security in Canada (de Loë et al. [5]), which revealed the following:

- Failing to involve stakeholders equitably can produce conflicts, as can failing to acknowledge and respect aboriginal water rights.

- Conflicts also can result when decision making relating to water allocation is not linked effectively with decision making around land use and economic development.

- A lack of transparency in decision making processes can create uncertainty, and can lead to poor investment decisions on the part of water users.

- $\quad$ Efforts to protect ecosystems through land-use planning, soil and water conservation programs, and water quality management initiatives can be undermined - or nullified - if water allocation systems ignore environmental water requirements.

- Carefully designed environmental water allocations can be undermined by a failure to recognize the impacts of decision making in other contexts, such as suburban development, waste water treatment, or aggregate development.

- The scale at which governance relating to water allocation should take place is a critical determinant of its success, and is highly context dependent. Equally context dependent is the appropriate role of nonstate actors in water governance (e.g., citizens, industries, nongovernment organizations) relative to state (government) actors.

\section{Conclusions}

In this paper, we argue that that irrigation is an important determinant of water security because of the volumes of water used, and the impacts of this use on communities and the environment. However, we also argue that broader water security concerns influence the long-term viability of the irrigation sector. In other words, irrigation affects water security, and water security affects irrigation. Water allocation systems can be an important vehicle for enhancing water security. In that context, economic instruments are a critical concern in that they facilitate allocative efficiency, and thereby can contribute to increased water security. However, by themselves economic instruments cannot create water security. Numerous other concerns relating to governance also must be addressed. Effective governance, we argue, demands attention to considerations such as transparency in decision making; equity in stakeholder involvement; appropriate linkages and integration among related systems (e.g., land and water, 
water and economy); the scale of decision making; and the balance between state and non-state actors.

\section{Acknowledgements}

This paper draws on a recent study of the relationship between water security and water allocation in Canada funded by the Walter and Duncan Gordon Foundation (de Loë et al. [5]). Becky Swainson (University of Guelph) conducted additional background research.

\section{References}

[1] Bazzani, G. M., Di Pasquale, S., Gallerani, V., Morganti, S., Raggi, M. and Viaggi, D. 2005. The sustainability of irrigated agricultural systems under the Water Framework Directive: first results. Environmental Modelling \& Software 20, no. 2: 165-175.

[2] Bjornlund, H. 2003. Efficient water market mechanisms to cope with water scarcity. Water Resources Development, 19(4): 553-567.

[3] Bjornlund, H. 2004. Formal and informal water markets: drivers of sustainable rural communities? Water Resources Research 40: 1-12.

[4] Cantin, B., Shrubsole, D. and Ait-Ouyahia. M. 2005. Using economic instruments for water demand management: Introduction. Canadian Water Resources Journal 30(1): 1-10.

[5] de Loë, R.C., Varghese, J., Ferreyra, C. and Kreutzwiser, R.D. 2007. Water Allocation and Water Security in Canada: Initiating a Policy Dialogue for the 21st Century. Report prepared for the Walter and Duncan Gordon Foundation. Guelph, ON: Guelph Water Management Group, University of Guelph.

[6] Dinar, A., and Mody, J. 2004. Irrigation water management policies: allocation and pricing principles and implementation experience. Natural Resources Forum, 28: 112-122.

[7] Dougherty, T.C., and Hall, A.W. 1995. Environmental Impact Assessment of Irrigation and Drainage Projects. FAO Irrigation and Drainage Paper No. 53. FAO: Rome, Italy.

[8] Ferreyra, C., and Van Beek, C. 2006. Valuing and allocating water resources I: Setting the stage. In Freshwater for the Future: Policies for Sustainable Water Management in Canada - Conference Proceedings, Gatineau, Québec, May 8-10. ed. Policy Research Initiative, 19-36. Ottawa, Ontario: PRI, Government of Canada.

[9] Gleick, P.H. 1998. Water in crisis: Paths to sustainable water use. Ecological Applications, 8(3): 571-79.

[10] Global Water Partnership. 2000. Towards Water Security: A Framework for Action. Stockholm, Sweden: GWP.

[11] Grimble, R.J. 1999. Economic instruments for improving water use efficiency: Theory and practice. Agricultural Water Management, 40: 7782. 
[12] Haestad Methods. No Date. "Your Guide to Water Security" (Accessed 25 May 2007). www.watersecurity.org.

[13] Kemper, K.E. 2001. The role of institutional arrangements for more efficient water re-sources use and allocation. Water Science and Technology, 43(4): 111-17.

[14] Massarutto, A. 2003. Water pricing and irrigation water demand: economic efficiency versus environmental sustainability. European Environment 13: 100-119.

[15] Oster, J.D. and Wichelns, D. 2003. Economic and agronomic strategies to achieve sustainable irrigation. Irrigation Science 22, no. 3-4: 107-120.

[16] Rosegrant, M.W., Cai, X., and Cline, S.A. 2002. Global Water Outlook to 2025: Averting an Impending Crisis. International Food Policy Research Institute: Washington, D.C.

[17] Warner, J.F., Bindravab, P.S. and Van Keulen, H. 2006. Introduction: Water for food and ecosystems: How to cut which pie? Water Resources Development, 22(1): 3-13.

[18] World Water Assessment Programme. 2003. Water for People, Water for Life: The United Nations World Water Development Report. UNESCO: Barcelona, Spain.

[19] Young, M. and McColl, J. 2008. A Future-Proofed Basin: a New Water Management Regime for the Murray-Darling Basin, Adelaide, South Australia: University of Adelaide. 